\title{
Maslow in the Mud. \\ Contrast between qualitative and quantitative assessment of thermal performance in historic buildings.
}

\author{
Dr Marcin Mateusz Kołakowski ${ }^{1[0000-0001-7244-1479]}$ \\ ${ }^{1}$ University of Lincoln, Lincoln LN6 7TS, UK \\ mkolakowski@lincoln.ac.uk
}

\begin{abstract}
This paper argues that the notion of comfort is first and foremost related to subjective choices and individual value systems. The article presents results from research on the perception and measurements of the thermal qualities of heritage buildings in Lincolnshire, UK. The qualitative and quantitative results identified a strong contrast between different methodologies. Inhabitants describe as comfortable houses which would not be considered comfortable if a standard positivist approach was used. The conflict presented will be discussed in the context of sustainable strategies in architecture.
\end{abstract}

Keywords: thermal comfort, heritage architecture, forgiveness factor, earth architecture, sustainable strategies in architecture.

... not everything that can be counted counts, and not everything that counts can be counted.

William Bruce Cameron [1]

\section{Introduction: who owns sustainability?}

Sustainable design - arguably the most important challenge of architecture today seems to be dominated methodologically by qualitative research and searching for technological solutions. Yet, the core of the problem seems to lie in human preferences and decisions - and those can be understood only from psychological perspectives. Researchers engaging with sustainability who go as far as to recognise the value of psychology sometimes make a 'methodological gesture' by referring to well-being and Maslow's pyramid. [2] It seems easy to use. It orders 'needs' hierarchically and linearly: physiological needs $\rightarrow$ security $\rightarrow$ social needs $\rightarrow$ esteem needs $\rightarrow$ selfactualisation... Richard Lupo [3] even claims that by following Maslow's theory we could understand the essence of well-being and achieve it on a global scale by simply satisfying basic needs: the right quantity of food and safe, dry and warm houses...

However, Maslow's system has been contested by many key figures of psychological schools such as Schaller, Neuberg, Griskevicius or Kenrick [4]. Erich Fromm, who developed his own psychological theory of needs, pointed out that "This list is 
a somewhat unsystematic enumeration, and regrettably Maslow did not try to analyse the common origin of such needs in the nature of Man" [5]. Basing on his own psychoanalytical research, Fromm claimed that commonly people are ready to sacrifice Maslowian basic needs and comfort in order to fulfil psychological needs which he defined as (1) relatedness - a need to relate to other living beings, (2) transcendence a need to belong to something larger than oneself, (3) rootedness - being able to define one's ideological framework, (4) sense of identity, and (5) the need for orientation and meaning [6].

Notably, Fromm's system sheds light on recent attempts to develop a humancentred approach in understanding the relationship between sustainable strategies in architecture and the set of values embraced by its users. This issue can be particularly clearly identified in the conflict between sustainable principles and the historical value of buildings.

Fouseki and Cassar [7] propose that the driving question for sustainable architecture - apart from technological aspects - should also be 'what does this building mean for those who use it?'. Architecture is a medium of adding meaning to a building, which brings relevance to the theory of Fromm but also of Bourdieu [8] who argues that the social dimension includes 'cultural capital' - a cultural identity which is mediated through features of buildings. Lynch [9] and Ingold [10] argue that a sense of meaning is often created by occupants' interaction with the building. This is particularly visible in the case of inhabitants who consciously decide to live in historic buildings.

Even Tweed and Sutherland [11], who initially tried to draw on Maslow's hierarchy, eventually came to the conclusion that utilitarian needs in architecture can be overrun by cultural appeal. These authors attempted to reconcile sustainability with other paradigms and concluded that heritage values in the built environment straddle the three pillars of sustainability - the economic, environmental and social dimensions. In their article entitled "Irrational homeowners? How aesthetics and heritage values influence thermal retrofit decisions in the United Kingdom", Sunikka-Blank and Galvin [12] found that homeowners develop their own sophisticated strategies for balancing between the need for retrofit and respecting heritage. They concluded that sustainability must consider cultural and heritage issues which cannot easily be quantified.

Unlike Sunikka-Blank and Galvin, who researched retrofitted houses and their owners, this paper presents results of 18-month-long research on a unique group of buildings and their inhabitants who seem content to compromise the conventional sense of comfort because they see value in living in Lincolnshire Mud \& Stud cottages - some of which were built over 400 years ago.

This research addresses a far greater issue - the sustainable agenda relating to the modernisation of historical building stock. This is a major global challenge considering that only in the UK, according to the National Statistics Survey, 21\% dwellings were built before 1919 and $85 \%$ before 1990, which is when thermal standards were first introduced [13]. 


\section{$2 \quad$ Research subject and methodology}

Vernacular style known as 'Mud and Stud' (M\&S) is claimed by local enthusiasts to be unique only to Lincolnshire in the UK [14]. According to renowned British building historian Maurice Barley, M\&S cottages are a unique type of buildings which were built for the poorest part of village society between 1400 and 1850 [15]. Barley claims that M\&S is one of the least known British building techniques. David Robert alarmed that Lincolnshire's vernacular tradition has been almost lost and has already been destroyed in great part [16].

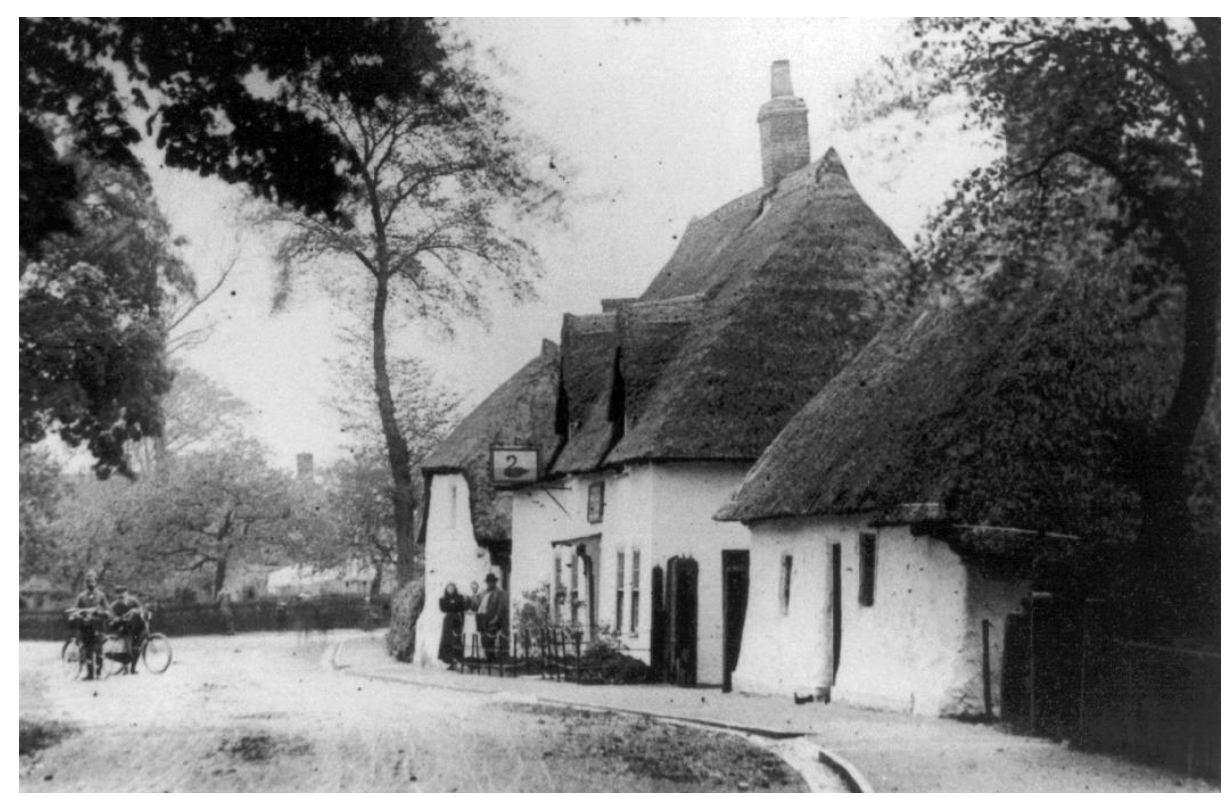

Fig. 1. Mud and stud cottage 'Black Swan' in Coningsby, Lincolnshire, UK, 1894.

However, since 1990s several researchers and enthusiasts have started to take a closer look at M\&S heritage. Naomi Field created first rigorous reports [17,18]. Building historian Rodney Cousins created a list of around 400 remaining M\&S buildings and published a monograph dedicated to this heritage. Cousins organised hundreds of talks dedicated to this Lincolnshire style contributing to its popularisation [14]. Architect David Glew looked at the possibility of adapting M\&S for new build $[19,20]$. M\&S buildings have slowly become local pride and started to be popularised thanks to the local group East Midlands Earth Structure Society (EMESS).

The M\&S construction - a method which Hugo Houben and Hubert Guillaud classify as 'cob on post' [21] - developed in Lincolnshire where good quality timber was scarce. Local builders developed a way of creating solid walls by combining timber sub-structure together with a thin earth cover. Built economically, M\&S cottages proved to be a very efficient way of using the materials available. Today they are 
valued for their architectural charm - central chimney, white walls and thick thatched roofing.

The research on M\&S buildings conducted between 2015 and 2018 by the author of this paper, dr Magdalena Baborska-Narożny and Ian Keeling, focused on both the thermal performance and the narratives associated with those buildings. Questionnaires with invitations to participate in the research and a return envelope were sent to all available 88 addresses of M\&S buildings from a catalogue created by EMESS. 23 questioners were returned with answers. For a further 'monitoring phase' of research, 12 cottages were chosen based on the criteria of best preserved features and accessibility. Selected cottages were all houses that inhabitants voluntarily decided to live in and were well aware of the heritage associated with M\&S. In the selected cottages, thermal and humidity sensors were installed which collected data over the period of 18 months. Three sensors were typically installed in each house: in the living room, kitchen and the bedroom. Thermal imaging was completed. About one-hourlong semi-structured interviews were conducted with the inhabitants. Qualitative and quantitative data were compared and cross-referenced [22]. This mixed methodology offered very contrasting results between the quantitative and qualitative data obtained.

\section{Contrast between qualitative and quantitative research}

Qualitative research based on interviews painted an overall very positive picture of $M \& S$ cottages. A common theme in all semi-structured interviews was the very positive emotions towards the cottages. When asked: 'Are you happy with this house?', all interviewees answered 'Yes' and offered additional explanations. One third of interlocutors praised their cottage's thermal properties claiming that the houses are "cosy and warm in winter". When asked "Does the building you live in meet your expectations regarding thermal performance?" one of the typical answers was: "Oh, yes. It's fantastic. I don't know why more people don't build out of mud". It is worth noticing that those answers seem to echo opinions presented in publications about earth buildings. Rodney Cousins wrote "these cottages are known for being cosy and warm in winter but cold in summer" [14].

However, those opinions stand in contrast to results of sensor monitoring. It must be noted, however, that readings from the sensors installed varied greatly. This is understandable taking into consideration the fact that $M \& S$ cottages were constructed over 400 years ago, and they have been readapted in manifold ways and various heating systems have been installed in them.

For the purpose of this paper, the contrast will be illustrated by an example of Cottage A (all names were anonymised). This building may be seen as representative since it still bears all the original features. The main central fireplace for coal and wood is still the main source of space heating. 1.5 tonnes of coal are used during the winter - "one basket a day". Sporadically, a $2 \mathrm{KW}$ oil electric heater is used additionally. An electric immersion heater is installed for heating water and shower. Coal stove and an electric cooker are in use in the kitchen. Inhabitants of Cottage A are 
enthusiastic about the quality of their home. In their opinion it is warm and provides a good environment to live in. It could be illustrated by statements such as: "It is warm in winter. It works really well."

Results derived from thermal imaging and sensor monitoring paint a somewhat different picture. Living room in Cottage A was the warmest place because this is where the fire place was located. According to the interviewees, this is also the place where the whole family spends most of the time. The kitchen and the bedroom were colder and the temperature there rarely exceeded $15^{\circ} \mathrm{C}$ and sometimes dropped below $10^{\circ} \mathrm{C}$ (see Fig. 2). The results presented below illustrate the sensor readings taken during the coldest month of February. The limitation of space does not allow presenting other months but even in April on several occasions the bedroom temperature fell to as low as $10^{\circ} \mathrm{C}$, whilst temperature in the kitchen rarely exceeded $15^{\circ} \mathrm{C}$. The average temperature (Fig. 3) does not reach the commonly accepted standards, such as those recommended by WHO (see below).

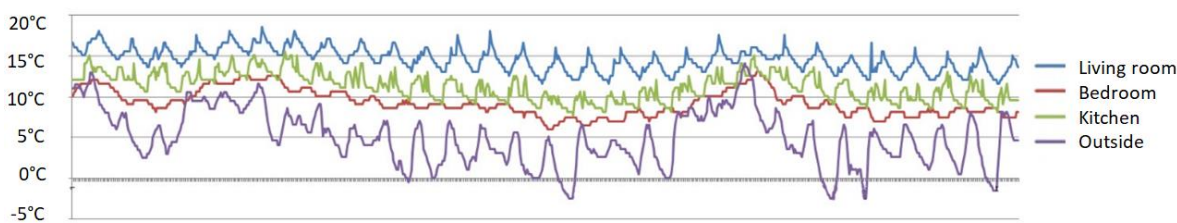

Fig. 2. Temperature sensor readings - Cottage A - Feb 2016

\begin{tabular}{|l|c|c|c|c|}
\hline \multicolumn{1}{|c|}{ Cottage A } & outside & living room & bedroom & kitchen \\
\hline November 2015 & $8.6^{\circ} \mathrm{C}$ & $16.9^{\circ} \mathrm{C}$ & $12.4^{\circ} \mathrm{C}$ & $14.0^{\circ} \mathrm{C}$ \\
\hline December 2015 & $9.7^{\circ} \mathrm{C}$ & $17.3^{\circ} \mathrm{C}$ & $13.1^{\circ} \mathrm{C}$ & $14.5^{\circ} \mathrm{C}$ \\
\hline January 2016 & $5.9^{\circ} \mathrm{C}$ & $15.1^{\circ} \mathrm{C}$ & $9.8^{\circ} \mathrm{C}$ & $11.7^{\circ} \mathrm{C}$ \\
\hline February 2016 & $5.0^{\circ} \mathrm{C}$ & $14.6^{\circ} \mathrm{C}$ & $9.3^{\circ} \mathrm{C}$ & $11.3^{\circ} \mathrm{C}$ \\
\hline March 2016 & $7.0^{\circ} \mathrm{C}$ & $14.8^{\circ} \mathrm{C}$ & $10.2^{\circ} \mathrm{C}$ & $11.9^{\circ} \mathrm{C}$ \\
\hline April 2016 & $9.8^{\circ} \mathrm{C}$ & $16.7^{\circ} \mathrm{C}$ & $12.6^{\circ} \mathrm{C}$ & $14.1^{\circ} \mathrm{C}$ \\
\hline
\end{tabular}

Fig. 3. Average temperature (sensor readings) - Cottage A

The results from thermal monitoring show that temperature often reached a level far below what could be expected from habitable buildings or homes described as 'warm and cosy'. In fact, the results obtained suggest conditions that are below the standard of indoor temperature recommended by The World Health Organization (WHO) which is $18^{\circ} \mathrm{C}$, and $21^{\circ} \mathrm{C}$ if babies or elderly people live in the house [23]. WHO recommendations echoed research by Kenneth Collins on the effect of low temperature on health: "At temperature below $16^{\circ} \mathrm{C}$, resistance to respiratory infections may be diminished. Both low and high relative humidities promote respiratory illnesses. At temperatures below $12^{\circ} \mathrm{C}$, cold extremities and slight lowering of core temperature 
can induce short-term increases in blood pressure" [24]. Thermal imaging demonstrated that in certain places, on cold days, the temperature of M\&S walls sometimes dropped to freezing point (Fig. 4).

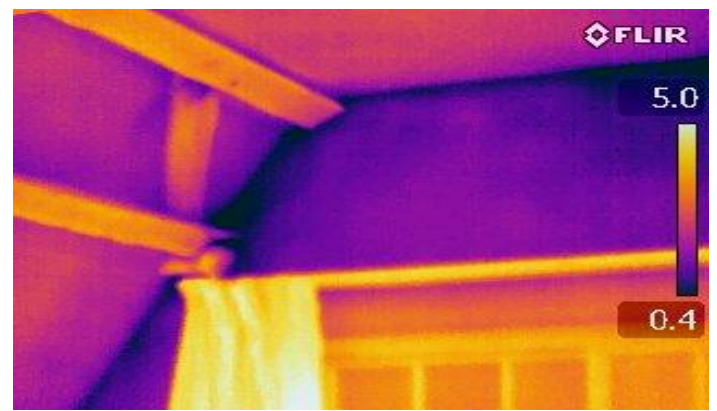

Fig. 4. Thermal imaging from inside of one of $M \& S$ cottages

From the point of view of this research, the most important question is, however, why do inhabitants of M\&S cottages claim that their homes are warm and comfortable? The answer could have an objective and subjective nature.

\section{Objective explanations of the contrasting results}

The objective results obtained from sensor monitoring were in accord with the theoretical modelling of the performance of earth walls which depends on their clay/straw mix, specific weight and additives. In the case of M\&S walls, the material consists of a straw-earth mix with weight of around $1600 \mathrm{~kg} / \mathrm{m}^{3}$. It offers thermal conductivity $(\Lambda)$ in the range of $0.8 \mathrm{~W} / \mathrm{mK}$, which for M\&S walls (usually $250-300 \mathrm{~mm}$ thick) translates into U-value of around $2 \mathrm{~W} / \mathrm{Km}^{2}$. This means that the thermal performance of M\&S walls is 6 times worse than the currently required UK standards of $0.3 \mathrm{~W} / \mathrm{Km}^{2}$. Any slight changes to the straw-earth mix or the wall thickness would not significantly change the fact that without considerable alteration those walls cannot offer the required insulation.

The thermal transmittance (U-value) does not describe all the properties of earth constructions. Another important factor which could positively influence the internal microclimate of earth constructions is the high thermal mass [25]. Once warmed up, due to thermal inertia, the wall 'keeps the warmth'. Walls radiate the heat and this could give a pleasant impression that despite the temperature fluctuations outdoors the house 'keeps its warmth'. This is also why earth walls could give an impression that they 'keep cold longer' on hot summer days and 'hold heat' during the cold winter days.

Secondly, due to its molecular structure, an unfired earth wall 'as if automatically' absorbs and releases water molecules offering natural regulation of humidity. This means that while mould could develop on conventional walls in lower temperature, earth walls are more resistant to this problem. The mechanism behind the phenome- 
non was described in detail by Minke [25]. The monitoring of humidity at M\&S houses, as predicted, identified relative humidity at the level of around $55 \%$ which is the recommended level from the health point of view. This result supports theoretical literature about earth architecture [25, 26].

Those positive aspects mitigate but do not change the fact that objectively the monitored houses were below expected standards of modern architecture in terms of thermal performance.

\section{Subjective explanations of the contrasting results}

The interviews shed light on how problems with performance have been overrun by other positive values of the house. This could be illustrated by an interview with two people A and B living together in one of the researched houses:

A: If you weren't careful, your bills would be phenomenal. Because if you wanted

to keep it at 22 degrees, you'd have to have the heating on ALL the time. I don't

know how you feel... you're probably not used to...

$B$ : It's quite hot when the fire is going.

A: At night-time I get the fire going because that's the time when I like to be warm.

B: I think I like the way with the central fire. The whole way the house is laid out.

Just how it works.

The analyses of answers from the returned questioners identified two groups: one, smaller group which is enthusiastic about the cottages, and the second, larger group, which is aware of the thermal issues but still enjoys living in M\&S. When asked a question about the positive aspects of living in a M\&S cottage, 17\% of respondents repeated the claim about the positive thermal properties of M\&S houses ("They are well insulated and warm in winter"). Other responses pointed to the general atmosphere ("It has an atmosphere which makes you feel good") (21\%), aesthetics (47\%), connection to history (39\%) and unique character (31\%). Answers related to "negative aspects' identified the awareness of problems of low thermal performance (52\%), high cost of living and maintenance (52\%) and restrictions connected with living in a historical building (39\%).

What is worth noting is that even those respondents who mentioned low thermal performance as the most problematic still greatly praise the way of living in a $M \& S$ cottage. The questionnaire also asked respondents to agree or disagree with a set of statements. The answer system followed the Likert scale (strongly agree, agree, no answer/don't know, disagree, strongly disagree). When asked about the statement "The building I live in meets my expectations regarding thermal comfort," twice as many respondents agreed or strongly agreed than disagreed or strongly disagreed. When asked about the statement "The building I live in is affordable with regards to bills, " 2.6 times more respondents agreed or strongly agreed than disagreed or strongly disagreed.

The seeming paradox of the contrast between the results could be explained by 'the forgiveness factor' also identified by other researches. Adrian Leaman and Bill Bordass noticed that overall the satisfaction with buildings described as 'green' could 
sometimes be greater that the satisfaction with individual elements. They believed that the green ethos is part of a 'psychological transaction'. "They trade-off good things against bad, reach compromises, and put up with shortcomings within reason'[26]. Leaman and Bordass called users who are ready to adapt and cope 'satisfiers'. It is a direct reference to the concept of Herbert A. Simon - a renowned economist, political scientist and cognitive psychologist - who used the concept of 'satisficing' to describe decision makers under circumstances in which an optimal solution cannot be determined [27]. As he put it "A 'satisficing' path is a path that will permit satisfaction at some specified level of all its needs" [28]. The 'forgiveness factor' related to green buildings has also been identified by Gou et.al. and Khoshbakht et.al [30] as well as Max Deuble and Richard de Dear [31].

Questionnaires and interviews with $M \& S$ inhabitants also provided strong indication that the factor which diminishes the problem of lack of comfort in this case is the positive attitudes towards heritage architecture, which is related to needs defined by Fromm, namely relatedness, transcendence, rootedness and sense of identity. Unlike Leaman and Bordass, who identified forgiveness related to green buildings, what played a decisive role in this case was the paradigm related to historical architecture, which was investigated through a set of questions. Respondents were asked to agree or disagree with a series of statements according to the Likert scale (Fig. 5-7). The results presented below identified strong tendencies toward favouring historical values in architecture over conventionally understood comfort.

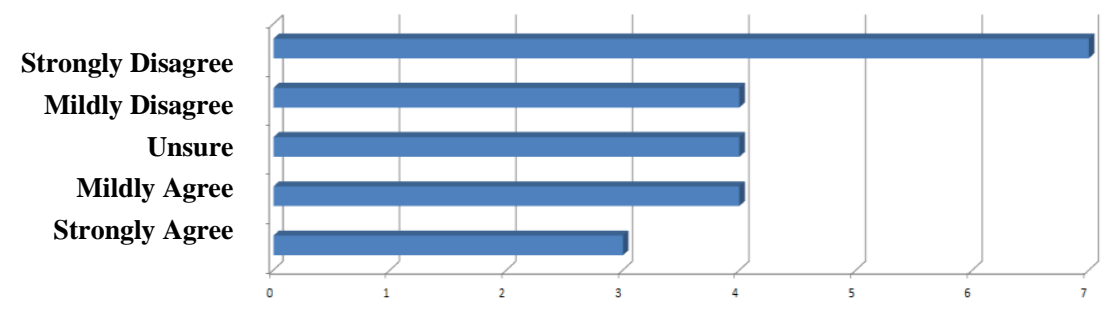

Fig. 5. Reaction to statement "If historical architecture does not respond to current needs, it should be changed, retrofitted or modernised"

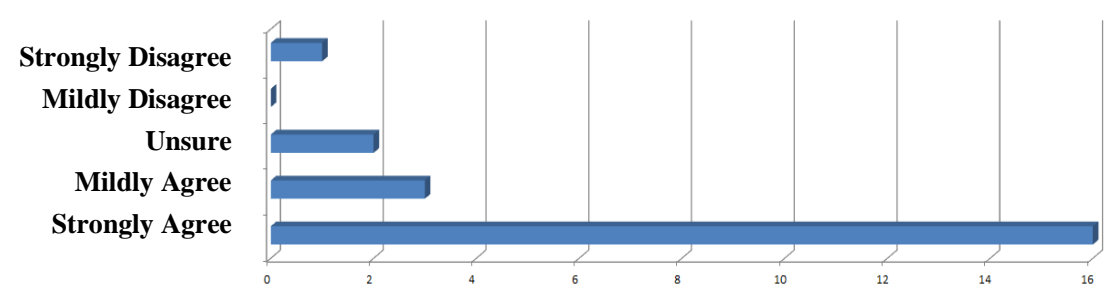

Fig. 6. Reaction to statement: "Living in historical buildings is particularly attractive because of their specific qualities and character" 


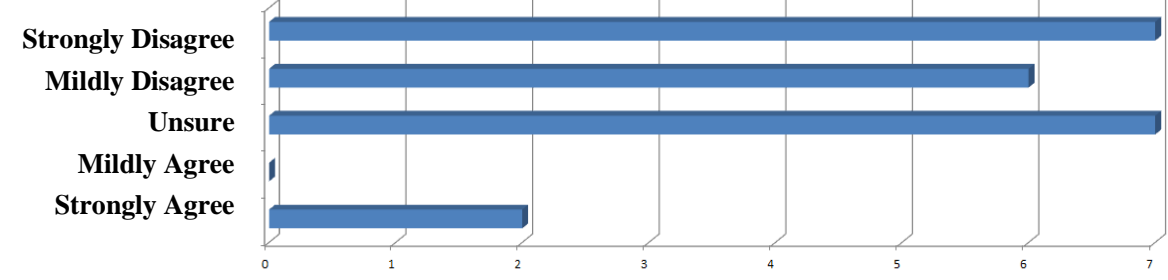

Fig. 7. Reaction to statement: "Historical architecture is interesting for historians and ethnographers but in order to meet current needs it would be better to invest in new high-quality architecture."

During the semi-structured interviews, inhabitants of the 12 selected M\&S cottages were asked direct question related to forgiveness: "Do you believe that the current internal climate you experience in your home would be acceptable if experienced within a modern equivalent?". In the case of this question, even those inhabitants who were very enthusiastic about their buildings admitted that they would expect better thermal quality if they were to live in a new build. All of them admitted that they would not mind even introducing technological solutions as long as they do not destroy the character of the cottage.

\section{Conclusions in relation to sustainability}

The question concerning reconciliation of individual and global needs in the context of sustainability is far from simple and poses methodological challenges. The research presented in this paper focused on heritage houses demonstrates how the positivist, quantitative assumptions according to which the performance of buildings can easily be translated into well-being of inhabitants may be very deceiving.

Those who decided to live in M\&S cottages see their homes as far more than shelters to live in. Their cottages are a way of belonging to a certain idea, group and tradition. Living in those houses is full of meaning and the inhabitants often feel that they are part of something greater than individual interest: "It is a privilege of being a guardian of heritage" stated one respondent during a research interview. This understanding of comfort may be better explained by Fromm's definitions of psychological concepts of relatedness, transcendence, rootedness, sense of identity and the need for meaning.

On the one hand, the research identified that M\&S buildings are thermally less efficient, whilst on the other hand, conscious users use energy in a much more frugal way. As a result, the overall energy balance may be surprisingly more sustainable. This kind of user behaviour must be a key factor in sustainable assessment.

The awareness of various paradigms should not prevent searching for solutions to improve the properties of historic buildings, but this should be done in a way that respects the value system of the inhabitants. It is important to note that users are not against improving the thermal performance of their dwellings even by means of high- 
tech solutions. What they are vehemently against is the callous indifference towards heritage and the dominance of quantitative factors over qualitative values.

The problem of sustainability is not the lack of know-how but rather a psychological deficiency - lack of will to engage with the idea of ecological consciousness. This is why the psychological perspective cannot be ignored while discussing sustainability. Smart cities or intelligent buildings are potentially interesting tools but the social and psychological sciences need to be incorporated into the assessment process and research. If the process of introducing the sustainability ethos is to succeed, it is crucial to recognise the fact that data, knowledge, know-how, information and intelligence are powerless where there is lack of meaning and wisdom, as T.S. Eliot said in his poem The Rock.

Where is the wisdom we have lost in knowledge?

Where is the knowledge we have lost in information?

\section{References}

1. Cameron W.: Informal Sociology: A Casual Introduction to Sociological Thinking. Random House, New York (1963).

2. Maslow, A.: Theory of Human Motivation. Psychological Review, 50(4): 370-396 (1943)

3. Lupo, R.: A Measure of Net Well-Being that Incorporates the Effect of Housing Environmental Impacts. BRE, London (2014).

4. Schaller, M., Neuberg, S., Griskevicius, V., Kenrick, D., Pyramid Power: A Reply to Commentaries. Perspectives on Psychological Science (5): pp. 335-337 (2010).

5. Fromm, E.,: Anatomy of Human Deconstructiveness. Holt Reinehard and Winston, New York (1973).

6. Fromm, E.: The Sane Society. Routledge, London (2002)

7. Fouseki K., M. Cassar: Energy efficiency in heritage buildings—future challenges and research needs, Hist. Environ.: Policy \& Pract. 5 (2) (2014)95-100.

8. Bourdieu P.: Distinction: A Social Critique of the Judgement of Taste, Routledge, London, (1984)

9. Lynch K.: The Image of the City, The MIT Press, Cambridge, MA, (1960).

10. Ingold T., The Perception of the environment: essays in livelihood, in: Dwelling and Skill, Routledge, London, 2000

11. Tweed C., Sutherland M.: Built cultural heritage and sustainable urban development, Landscape Urban Plann. 83 (1) (2007) 62-69.

12. Sunikka-Blank, M., Galvin, R.: Irrational homeowners? How aesthetics and heritage values influence thermal retrofit decisions in the United Kingdom, Energy Research and Social Science, 11: p 97-108. (2015).

13. Department for Communities and Local Government: English Housing Survey Housing stock report. DC\&LG Publication London (2008)

14. Cousins. R.: Lincolnshire Buildings in the Mud and Stud Tradition. Heritage Trust of Lincolnshire, Sleaford (2000).

15. Barley, M.: Lincolnshire and the Fens. B T Batford Ltd, London. p.28 (1952). 
16. Roberts D. L.: The Vernacular Buildings of Lincolnshire. Archaeological Journal 131: pp. 298-308 (1974).

17. Field, N.: Withern Cottage. In: N. Field and A. White (eds) A Prospect of Lincolnshire. Lincoln pp. 92-5 (1984).

18. Field, N. Mainly Mud and Stud. In: Vernacular Architecture Group, Spring Conference: Lincoln (2016).

19. Glew, D.: New Mud-and-Stud Construction in England and the Problem of Thermal Insulation. In: Proceedings of Terra 2012 Terra 2012: XIth International Conference on the Study and Conservation of Earthen Architectural Heritage (22-27 April 2012), Pontifical Catholic University of Peru, Lima (2012).

20. Glew, D.: Mud-and-Stud Construction: Compliance with modern planning and building regulations. In: English Heritage, Terra 2000 8th International Conference on The Study and Conservation of Earthen Architecture. Torquay (UK) p 139-143 (2000).

21. Houben, H., Guillard, H.: Earth Construction: A Comprehensive Guide, Intermediate Technology Publication, London, p 188 (1994).

22. Kołakowski, M.: How to measure well-being in architecture: The benefits of using mixedmethod research. Architectus, 49 (1) pp. 15-32 (2017).

23. World Health Organization: The Effects of the Indoor Housing Climate On the Health of The Elderly (September). Graz (1982).

24. Collins, K.: Low Indoor Temperatures and Morbidity in The Elderly. Age and Ageing, 15 (4): p 212-220 (1986).

25. Minke, G.: Building with Earth: Design and Technology of a Sustainable Architecture. Birkhäuser, Berlin. pp 15-17 (2006).

26. Leaman, A., Bordass, B.: Are Users More Tolerant of 'Green buildings'? Building Research \& Information, 635 (6): pp.662-673 (2007).

27. Simon, H. A.: Rational Choice and the Structure of the Environment. Psychological Review. 63 (2): pp. 129-138. (1956).

28. Ibid. p. 136

29. Gou, Z., Prasad, D., Lau, S., Siu, Y.: Are Green Buildings More Satisfactory and Comfortable? Habitat International 39: pp 156-161(2013).

30. Khoshbakht, M., et.al: Are green Buildings more Satisfactory? A Review of Global Evidence Habitat International 74: p 57-65. (2018).

31. Deuble, M., de Dear R.: Green occupants for green buildings: The missing link? In: Proceedings of Conference: Adapting to Change: New Thinking on Comfort, Cumberland Lodge, Windsor, UK, 9-11 April 2010. Network for Comfort and Energy Use in Buildings, London (2012). 